\title{
Mineral Chemistry and Thermobarometry of the Volcanic Rocks in Torud, Iran
}

\author{
Elham Shah Hosseini' ${ }^{1}$ Afshin Ashja Ardalan', Mohammad Hashem Emami ${ }^{3}$, \\ Mohammad Hossein Razavi ${ }^{4}$ \\ ${ }^{1}$ Department of Geology, North Tehran branch, Islamic Azad University, Tehran, Iran \\ ${ }^{2}$ Department of Geology, North Tehran Branch, Islamic Azad University, Tehran, Iran \\ ${ }^{3}$ Department of Geology, Eslamshahr Branch, Islamic Azad University, Eslamshahr, Iran \\ ${ }^{4}$ Department of Geology, Faculty of Sciences, Kharazmi University, Tehran, Iran \\ Email: elham2shahosiny@yahoo.com
}

Received 7 July 2014; revised 5 August 2014; accepted 1 September 2014

Copyright (C) 2014 by authors and Scientific Research Publishing Inc.

This work is licensed under the Creative Commons Attribution International License (CC BY).

http://creativecommons.org/licenses/by/4.0/

c) (7) Open Access

\begin{abstract}
This paper elucidates the compositional studies on clinopyroxene, plagioclase of basalts to andesitic rocks of Torud area to understand the geotectonic and geothermobarometry conditions. Early Eocene-Oligocene calc-alkaline volcanic rocks are exposed around Torud in the Central Iranian zone. Volcanic rocks consist of basaltic, andesite basalt, Tracyandesite, and andesite. Minerals in the volcanic rocks exhibit degrees of disequilibrium features. Plagioclase as dominant mineral in these rocks generally displays oscillatory zoning. Mineral chemistry studies show that clinopyroxenes in the volcanic rocks are diopside, augite and plotted in medium pressure field. The clinopyroxene composition yields the crystallization temperatures $900^{\circ} \mathrm{C}-1000^{\circ} \mathrm{C}$. The mineral composition indicates that these rocks are formed in a tensional environment.
\end{abstract}

\section{Keywords}

Volcanic Rocks, Mineral Chemistry, Clinopyroxenes, Plagioclase, Torud

\section{Introduction}

Central Iran is one of the main and most complex geological zones of Iran (Figure 1). The oldest metamorphism (Precambrian) and the youngest semi-active volcanism occurred in this zone. In fact, this region is the oldest micro-continent plate in Iran which has suffered various geological processes. One of the most important and interesting geological events in Iran is the occurrence of orogenic movements comparable with the Katangan in 


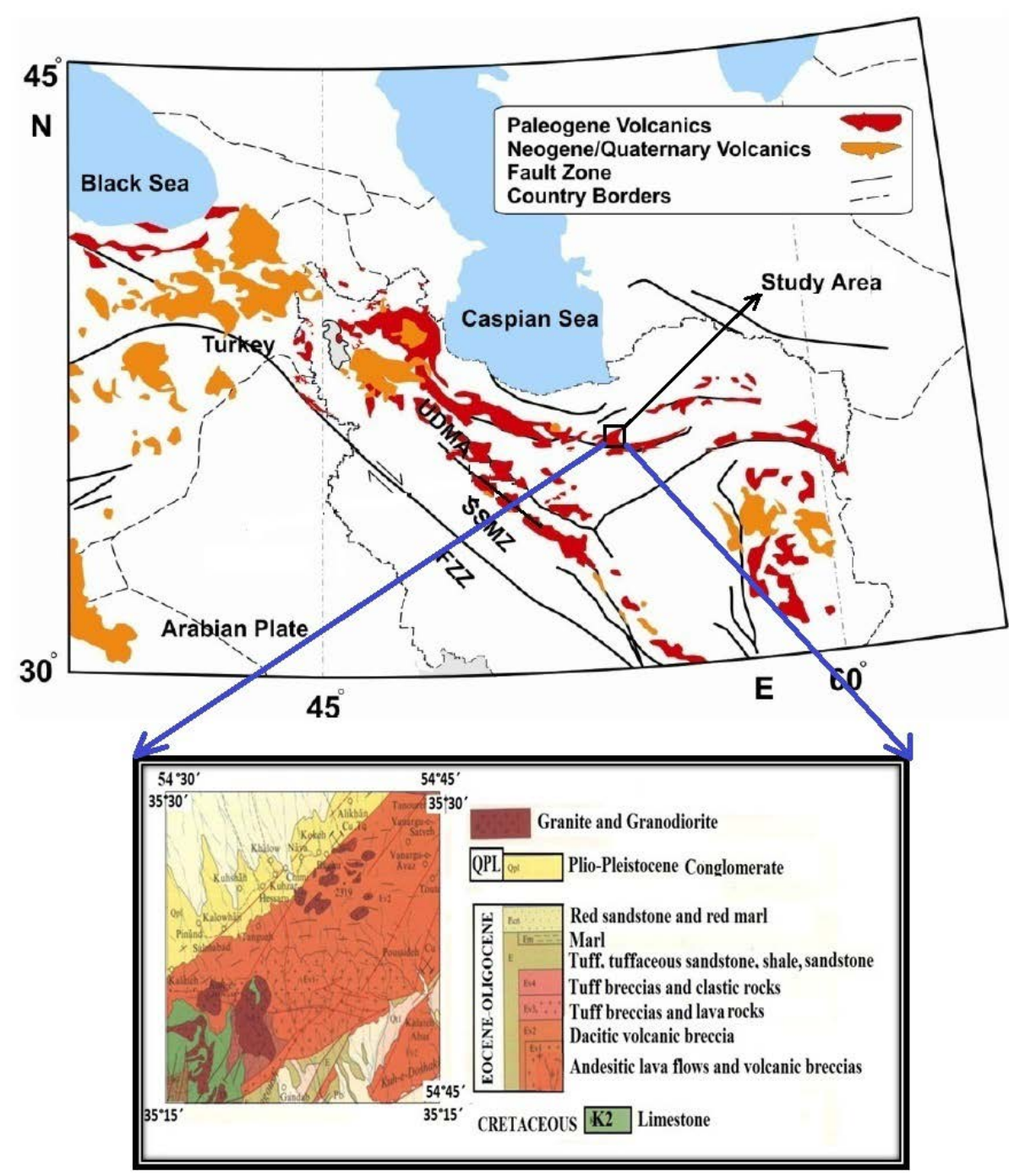

Figure 1. Geographical location of the study area of $(1: 250,000)$ Troud map (Houshmandzadeh, Alavi, Right Pvr, 1357) [14].

Gondwanaland and Baikalian in the Eurasian continent. In Central East Iran the Microplate was more or less connected to the southern rim of Eurasia during the Paleozoic and early Mesozoic. A significant separation from Eurasia took place during the Jurassic (Soffel and Forster, 1984) [1]. As a result of Neo-Tethys subduction beneath the Central Iran Microplate (CIM) and following the collision of Iranian and Afro-Arabian plates, various structural zones developed in Iran (Alavi, 2004, Nadimi, 2007, Sengör and Yilmaz, 1981 and Ahmadzadeh, Jahangiri, Lentz and Mojtahedi, 2010) [2]-[5]. However, peak of this subduction-related calc-alkaline magmatic activity is thought to have been in the Eocene age (Stocklin, 1973, Farhoudi, 1978, Emami, 1981, Jahangiri, 2007, Berberian and King, 1981, Dupuy and Dostal, 1984, Azizi and Jahangiri, 2008, Jung, Küsten and Tarkian, M., 1976) [6]-[13]. The area under studied is located in the $115 \mathrm{~km}$ south of Damghan city and120 km north southwest of Shahrood with 70 square kilometers. And longitudes of $54^{\circ} 30^{\prime}$ and $54^{\circ} 45^{\prime}$ and latitudes of $35^{\circ} 15^{\prime}$ and $35^{\circ} 30^{\prime}$ (Figure 1) are part of Troud 1:250000 scale map of Central Iran micro plate.

\section{Geology}

Volcanic rocks and volcanic - sedimentary rocks of Middle to Upper Eocene in Torud area are composed of lava alternate with basic-intermediate pyroclastic rocks and they are deposited with the sedimentary layers (siltstone, nummulities bearing limestone) in a shallow marine environment. Combined spectrum of volcanic rocks 
consisting of basalt, andesite, trachyandesite, andesite and dacite were obtained by fractional crystallization and eventually contamination process, and clinopyroxene, amphibole and plagioclase, are the major minerals in the rocks. Porphyritic to mga-Porphyritic textures microlithic groundmass are the nature of these rocks. These features are along with its alkaline nature, and represent rocks formed in a back-arc tectonic position of the Middle Eocene-upper area.

\section{Analytical Methods}

In order to achieve the aims of this work, at the first field surveying and sampling was done, then thin and 38 thin polished sections were prepared. About the rocks of area, 5 rocks include andesitic basalt, basaltic 39 andesite and andesite were selected for microprobe analysis and their olivine, clinopyroxene and 40 plagioclase minerals by using XGT-7200 micro-XRF analyzer-Horiba with voltage of $50 \mathrm{kv}$ and a 41 current of $3 \mathrm{~mA}$ in Kansaran Binaloud Laboratory were analyzed. A total of 80 points was analyzed 42 which results of this analysis are given in Tables 1-3.

Table 1. EPMA data of representative plagioclases from basalts to andesite composition of Torud area.

\begin{tabular}{|c|c|c|c|c|c|}
\hline \multicolumn{6}{|c|}{ PL } \\
\hline & E28-b-1 & E28-b-2 & E75-An-1 & E75-An-2 & E65-An-1 \\
\hline Element & Mass (\%) & Mass (\%) & Mass (\%) & Mass (\%) & Mass (\%) \\
\hline $\mathrm{Na}_{2} \mathrm{O}$ & 0.01 & 4.37 & 6.64 & 4.09 & 5.45 \\
\hline $\mathrm{Al}_{2} \mathbf{O}_{3}$ & 19.12 & 23.38 & 22.18 & 23.58 & 22.3 \\
\hline MgO & 18.31 & 0.09 & 0.49 & 0.81 & 0.5 \\
\hline $\mathrm{CaO}$ & 9.45 & 12.53 & 4.02 & 5.95 & 5.4 \\
\hline $\mathbf{P}_{2} \mathbf{O}_{5}$ & 0 & 0 & 0.04 & 0.01 & 0.01 \\
\hline $\mathrm{Fe}_{2} \mathrm{O}_{3}$ & 5.96 & 0.77 & 0.7 & 0.79 & 0.7 \\
\hline $\mathrm{SiO}_{2}$ & 45.82 & 57.57 & 64.48 & 63.33 & 64.5 \\
\hline $\mathrm{K}_{2} \mathrm{O}$ & 0.16 & 1.07 & 1.26 & 1.16 & 1.2 \\
\hline $\mathrm{Cr}_{2} \mathrm{O}_{3}$ & 0 & 0 & 0 & 0 & 0 \\
\hline $\mathbf{R} \mathbf{b}_{2} \mathbf{O}$ & 0 & 0.01 & 0 & 0.01 & 0.01 \\
\hline $\mathrm{ZrO}_{2}$ & 0.01 & 0.01 & 0.01 & 0.01 & 0.01 \\
\hline $\mathrm{SO}_{3}$ & 0.01 & 0.02 & 0 & 0.04 & 0.04 \\
\hline SrO & 0.01 & 0.07 & 0.09 & 0.09 & 0.09 \\
\hline $\mathrm{MnO}_{2}$ & 0.93 & 0.06 & 0.03 & 0.05 & 0.03 \\
\hline $\mathrm{TiO}_{2}$ & 0.07 & 0.03 & 0.05 & 0.04 & 0.04 \\
\hline $\mathrm{V}_{2} \mathrm{O}_{5}$ & 0.05 & 0.02 & 0 & 0 & 0 \\
\hline $\mathrm{ZnO}$ & 0.06 & 0 & 0 & 0.03 & 0.03 \\
\hline Total & 99.97 & 100 & 99.99 & 99.99 & 100.31 \\
\hline $\mathrm{SiO}[2]$ & 1.84 & 2.31 & 2.58 & 2.55 & 2.57 \\
\hline TiO[2] & 0.00 & 0.00 & 0.00 & 0.00 & 0.00 \\
\hline $\mathrm{Al}[2] \mathrm{O}[3]$ & 1.02 & 1.25 & 1.18 & 1.27 & 1.18 \\
\hline $\mathrm{Cr}$ & 0.00 & 0.00 & 0.00 & 0.00 & 0.00 \\
\hline $\mathrm{FeO}$ & 0.48 & 0.06 & 0.06 & 0.06 & 0.06 \\
\hline MnO & 0.08 & 0.01 & 0.00 & 0.00 & 0.02 \\
\hline MgO & 1.47 & 0.01 & 0.04 & 0.02 & 0.04 \\
\hline $\mathrm{CaO}$ & 0.76 & 1.00 & 0.32 & 0.48 & 0.43 \\
\hline $\mathrm{Na}[2] \mathrm{O}$ & 0.00 & 0.70 & 1.06 & 0.66 & 0.87 \\
\hline $\mathrm{K}[2] \mathrm{O}$ & 0.03 & 0.17 & 0.20 & 0.19 & 0.19 \\
\hline Total & 5.66 & 5.50 & 5.46 & 5.23 & 5.36 \\
\hline Or & 3.269 & 9.141 & 67.003 & 49.726 & 58.29 \\
\hline $\mathbf{A b}$ & 0.204 & 37.334 & 20.283 & 36.17 & 28.88 \\
\hline An & 96.527 & 53.524 & 12.714 & 14.103 & 12.83 \\
\hline
\end{tabular}


Table 2. Type of plagioclase using Spreadsheet.

\begin{tabular}{ccccc}
\hline Samples & Or & Ab & An & Sum \\
\hline E69-BA-1 & 3.56 & 0.45 & 95.9 & 100 \\
E69-BA-2 & 3.67 & 0.86 & 95.47 & 100 \\
E28-BA-1 & 3.269 & 0.204 & 96.52 & 100 \\
E28-BA-2 & 9.141 & 37.334 & 53.52 & 99.99 \\
E115-Ba-1 & 2.75 & 3.66 & 93.59 & 100 \\
E115-Ba-2 & 2.87 & 0.65 & 96.48 & 100 \\
E94-GA-1 & 57.203 & 15.352 & 27.445 & 100 \\
E94-GA-2 & 68.928 & 16.519 & 14.553 & 100 \\
E75-AN-1 & 67.003 & 20.283 & 12.714 & 100 \\
E75-AN-2 & 49.726 & 36.17 & 14.103 & 99.99 \\
E65-An-1 & 58.288 & 28.877 & 12.834 & 100 \\
\hline
\end{tabular}

Table 3. EPMA data of representative Clinopyroxene from basalts to andesite composition of Torud area.

\begin{tabular}{|c|c|c|c|c|c|c|c|c|c|c|}
\hline CPX & E38-Ba-1 & E38-Ba-2 & E38-Ba-3 & E6-BA & E12-AN-1 & E12-AN-2 & E12-AN-3 & E21-AN-1 & E21-AN-2 & E21-AN-3 \\
\hline Element & Mass (\%) & Mass (\%) & Mass (\%) & Mass (\%) & Mass (\%) & Mass (\%) & Mass (\%) & Mass (\%) & Mass (\%) & Mass (\%) \\
\hline $\mathrm{Na}_{2} \mathrm{O}$ & 0.03 & 0.21 & 1.38 & 1.22 & 0.1 & 0.36 & 0.11 & 0.25 & 0.2 & 0.178 \\
\hline $\mathbf{A l}_{2} \mathbf{O}_{3}$ & 2.67 & 2.25 & 5.3 & 5.4 & 2.19 & 1.84 & 1.83 & 2.23 & 2.14 & 1.35 \\
\hline MgO & 17.56 & 14.65 & 12.31 & 12.46 & 14.55 & 14.22 & 14.01 & 14.25 & 14.8 & 15.2 \\
\hline $\mathrm{CaO}$ & 18.46 & 18.97 & 16.64 & 17.2 & 19.91 & 18.99 & 20.06 & 20.36 & 21 & 20.12 \\
\hline $\mathbf{P}_{2} \mathbf{O}_{5}$ & 0.51 & 0 & 0 & 0 & 0.01 & 0 & 0 & 0 & 0 & 0 \\
\hline $\mathrm{Fe}_{2} \mathrm{O}_{3}$ & 8.22 & 9.85 & 10.43 & 11.72 & 8.7 & 7.9 & 8.18 & 8.5 & 7.5 & 7.5 \\
\hline $\mathrm{SiO}_{2}$ & 52.04 & 53 & 51.91 & 51.03 & 53.51 & 55.88 & 55.14 & 53.25 & 52.63 & 55.34 \\
\hline $\mathrm{K} 2 \mathrm{O}$ & 0.02 & 0.01 & 0.26 & 0.28 & 0.02 & 0 & 0 & 0.12 & 0.19 & 0.14 \\
\hline $\mathrm{Cr}_{2} \mathrm{O}_{3}$ & 0 & 0 & 0.11 & 0.11 & 0 & 0 & 0.03 & 0.03 & 0.03 & 0.03 \\
\hline $\mathbf{R} \mathbf{b}_{2} \mathbf{O}$ & 0 & 0.01 & 0.01 & 0.01 & 0 & 0 & 0 & 0 & 0 & 0 \\
\hline $\mathrm{ZrO}_{2}$ & 0.02 & 0.02 & 0.01 & 0.01 & 0.01 & 0.02 & 0.02 & 0.02 & 0 & 0 \\
\hline $\mathrm{SO}_{3}$ & 0.01 & 0.01 & 0.04 & 0.04 & 0.05 & 0.01 & 0 & 0.04 & 0 & 0 \\
\hline SrO & 0.01 & 0.01 & 0.01 & 0.01 & 0.01 & 0 & 0 & 0 & 0 & 0 \\
\hline $\mathrm{MnO}_{2}$ & 0.31 & 0.38 & 0.33 & 0.35 & 0.44 & 0.42 & 0.55 & 0.4 & 0.5 & 0.5 \\
\hline $\mathrm{TiO}_{2}$ & 0.51 & 0.57 & 0.71 & 0.75 & 0.49 & 0.33 & 0 & 0.45 & 0.44 & 0.5 \\
\hline $\mathrm{V}_{2} \mathrm{O}_{5}$ & 0.08 & 0.06 & 0.08 & 0.08 & 0 & 0.04 & 0.06 & 0.05 & 0.05 & 0.05 \\
\hline $\mathrm{ZnO}$ & 0 & 0 & 0 & 0 & 0 & 0 & 0 & 0 & 0 & 0 \\
\hline Total & 100.43 & 112.31 & 99.53 & 100.67 & 99.99 & 100.01 & 99.99 & 99.95 & 99.48 & 100.908 \\
\hline $\mathrm{SiO}[2]$ & 1.919 & 1.928 & 1.966 & 1.90 & 2.025 & 2.039 & 1.977 & 0.983 & 1.01 & 2.014 \\
\hline $\mathrm{TiO}[2]$ & 0.014 & 0.020 & 0.016 & 0.02 & 0.000 & 0.009 & 0.014 & 0.008 & 0.00 & 0.011 \\
\hline $\mathrm{Al}[2] \mathrm{O}[3]$ & 0.116 & 0.232 & 0.098 & 0.24 & 0.079 & 0.079 & 0.095 & 0.066 & 0.05 & 0.058 \\
\hline $\mathrm{Cr}$ & 0.000 & 0.003 & 0.000 & 0.00 & 0.001 & 0.002 & 0.000 & 0.000 & 0.00 & 0.001 \\
\hline FeO & 0.253 & 0.324 & 0.305 & 0.36 & 0.251 & 0.241 & 0.269 & 0.305 & 0.25 & 0.228 \\
\hline MnO & 0.010 & 0.010 & 0.012 & 0.01 & 0.017 & 0.013 & 0.014 & 0.012 & 0.02 & 0.015 \\
\hline MgO & 0.966 & 0.682 & 0.810 & 0.69 & 0.767 & 0.773 & 0.801 & 0.810 & 0.77 & 0.825 \\
\hline $\mathrm{CaO}$ & 0.729 & 0.662 & 0.754 & 0.69 & 0.789 & 0.742 & 0.788 & 0.754 & 0.79 & 0.784 \\
\hline $\mathrm{Na}[2] \mathrm{O}$ & 0.002 & 0.132 & 0.015 & 0.09 & 0.008 & 0.025 & 0.007 & 0.030 & 0.02 & 0.013 \\
\hline $\mathrm{K}[2] \mathrm{O}$ & 0.001 & 0.012 & 0.000 & 0.01 & 0.000 & 0.000 & 0.001 & 0.001 & 0.00 & 0.006 \\
\hline Total & 4.011 & 4.006 & 3.977 & 4.01 & 3.938 & 3.924 & 3.966 & 2.969 & 2.91 & 3.955 \\
\hline Wo & 37.20 & 36.59 & 39.71 & 37.27 & 42.98 & 41.24 & 41.88 & 42.74 & 41.24 & 42.97 \\
\hline En & 49.30 & 37.67 & 42.68 & 37.58 & 41.77 & 42.97 & 42.59 & 41.63 & 42.97 & 42.97 \\
\hline Fs & 13.39 & 18.45 & 16.82 & 20.37 & 14.82 & 14.37 & 15.14 & 14.68 & 14.37 & 42.97 \\
\hline Ac & 0.11 & 7.28 & 0.80 & 4.78 & 0.43 & 1.41 & 0.38 & 0.95 & 1.15 & 0.67 \\
\hline
\end{tabular}




\section{Discussion}

\subsection{Plagioclases}

Plagioclase (PLAG) is largely unaltered in rocks from this site and shows a distinct difference in habit related to the type of occurrence and the magmatic affinity of the host lava. It occurs either as phenocrysts or microlites. Plagioclase compositions determined by microprobe are listed in Table 1 . The overall and range is $97 \%-30 \%$, so the majority of plagioclase crystals are oligoclase, andesine, labradorite, by townite and anorthite in composition between basalt and esite to andesite composition. PLAG plotting in the ternary classification diagram Ab-An-Or (Figure 2) shows that there may be some overlap between phenocrysts of each magma compositions. The petrographic evidence that the PLAG was the liquidus phase is confirmed by the occurrence of individuals relatively rich in anorthite component (up to 95\%). The most An-rich plagioclase phenocrysts occur in the Basalt rocks, while the most An-poor crystals are from the Andesitic rocks (Figure 2). Of albite, anorthite and alkali feldspar component is determined by the file Spreadsheet (Table 2).

The textural and compositional disequilibrium evidences in plagioclase are important. Sieve texture and zonation of plagioclase is noticeable in these volcanic rocks (Figure 3). This may be interpreted as resulting from either partial dissolution during the magma mixing process (Feeley and Dungan, 1996) [15], or a decompression effect (Nelson and Montana, 1992) [16].

\subsection{Clinopyroxene}

Clinopyroxene is one of the most abundant mineral phases in the mafic-intermadiate, calc-alkaline rocks from study areas. It occurs as large (up to $4 \mathrm{~mm}$ ) isolated phenocrysts, glomerocrysts, microphenocrysts, and as a groundmass phase. The compositions of clinopyroxenes are predominantly augite and diopside according to the classification (Morimoto, 1989) [17] (Table 3) (Figure 4). Reverse zoning of phenocrysts can be explained by a number of processes, including: 1) decompression during magma ascent (Kontak, et al., 1984) [18]; 2) more oxidizing conditions during later stages of crystallization (Luhr and Carmicheal, 1980) [19] and (Grunder and Mahood, 1988) [20]; or 3) magma mixing (Nixon and Pearce, 1987) [21]. Sector zoning also occurs in some samples and can be interpreted to have originated from rapid crystal growth (Morrice and Gill, 1986) [22]. Of Anstatie Frosilit, Actinolite and Wollastonite component is determined by the file Spreadsheet (Table 4).

Experimental and petrological studies have demonstrated that partitioning of minor elements (e.g., $\mathrm{Ti}$ and $\mathrm{Al}$ ) in pyroxene is strongly growth-rate dependent, although equilibrium partitioning of $\mathrm{Ca}, \mathrm{Mg}$ and Fe may not be seriously affected by cooling rates (Gamble and Taylor 1980) [23] and hence increase in Al/Ti ratios even in liquids fractionating plagioclase (Table 2 and Table 3). On the pyroxene classification of (Morimoto, 1988) [17]

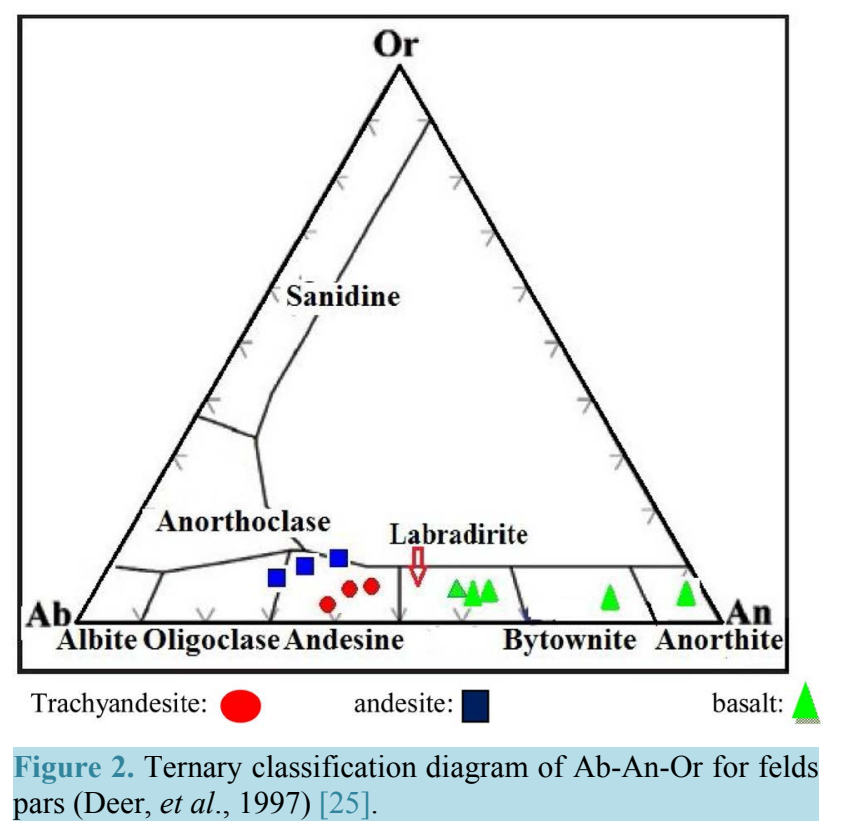



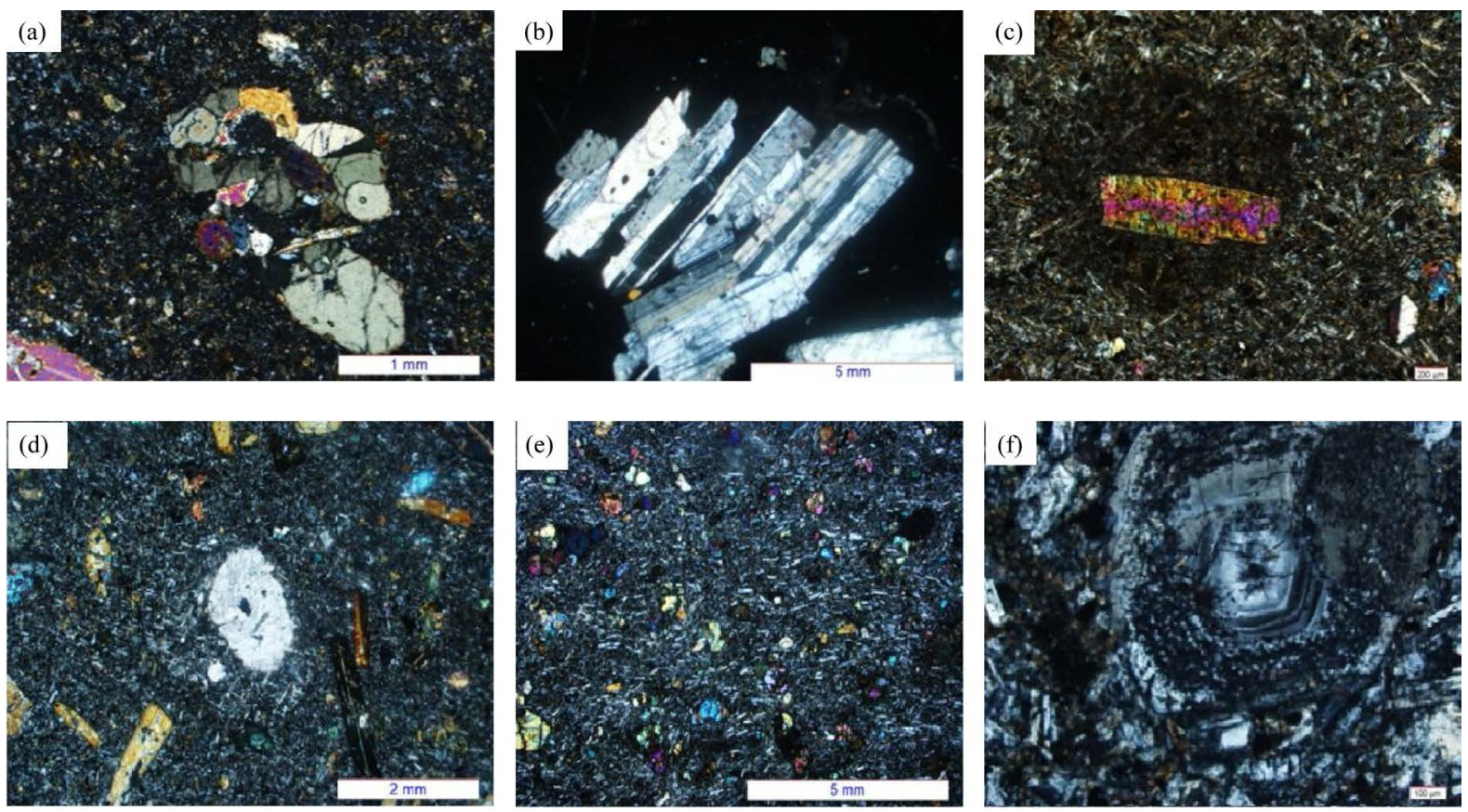

Figure 3. Photomicrographs of thin sections of lavas: (a) pyroxen phenocrysts in a andesite (XPL); (b) plagioclase phenocrysts in a basaltic andesite (XPL); (c) clinopyrpxene with microlitic texture in andesite basalt (XPL); (d) amphibole crystals extracted from a cavity filled by calcite in the andesite; (e) the mikrolite rounded olivine and plagioclase with clinopyroxene phenocrysts of the lavas tracks mikrolite andesitic basalt and porphyritic texture create Stream; and (f) plagioclase phenocrysts with reaction and sieve-textured, resorption-generated zone in mixed lavas (XPL).

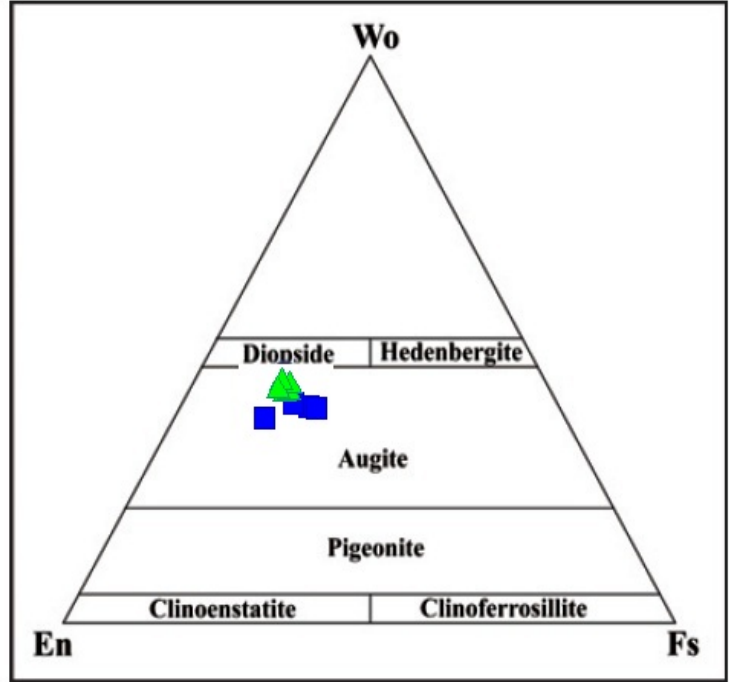

(a)

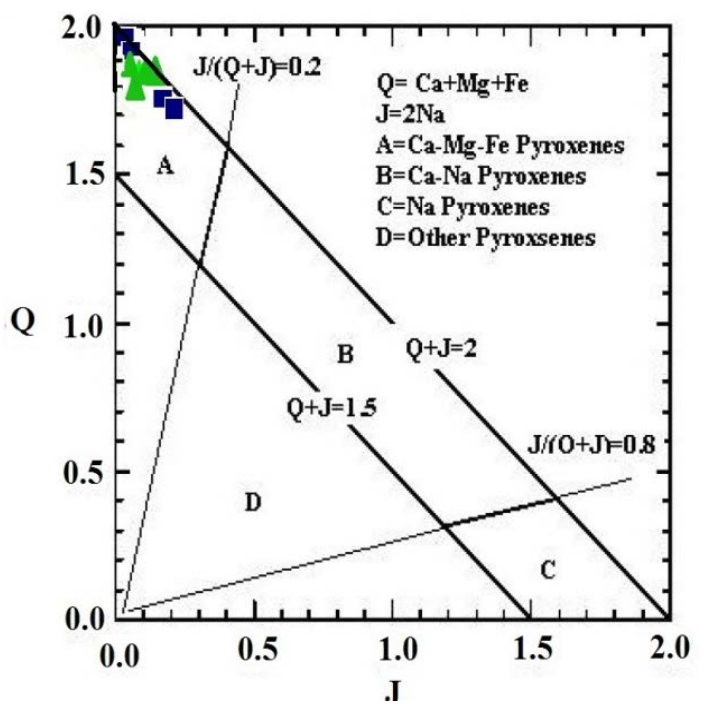

(b)

Figure 4. Composition of clinopyroxenes from Tafresh volcanic rocks are plotted in (a) (Deer, et al., 1997) [25], and (b) the Q-J clinopyroxene classification diagram (Morimoto, 1988) [17].

the pyroxenes plot in the augite field approaching diopside compositions, similar to pyroxenes from other orogenic volcanic rocks (Ewart, 1979) [24] (Figure 4).

\subsection{Evaluation of Oxygen Fugacity}

Oxygen fugacity plays an important role in changing of the liquidus temperature, melt and crystals composition 
Table 4. Type of clinopyroxen using Spreadsheet.

\begin{tabular}{cccccc}
\hline Samples & Wo & En & Fs & Ac & Sum \\
\hline E38-BA-1 & 37.20 & 49.30 & 13.39 & 0.11 & 100.00 \\
E38-BA-2 & 36.59 & 37.67 & 18.45 & 7.28 & 100.00 \\
E38-BA-3 & 39.71 & 42.68 & 16.82 & 0.80 & 100.00 \\
E6-BA-1 & 37.27 & 37.58 & 20.37 & 4.78 & 100.00 \\
E12-AN-1 & 42.98 & 41.77 & 14.82 & 0.43 & 100.00 \\
E12-AN-2 & 41.24 & 42.97 & 14.37 & 1.41 & 100.00 \\
E12-AN-3 & 41.88 & 42.59 & 15.14 & 0.38 & 100.00 \\
E21-An-1 & 42.74 & 41.63 & 14.68 & 0.95 & 100.00 \\
E21-AN-2 & 43.55 & 42.71 & 13.00 & 0.75 & 100.00 \\
E21-AN-3 & 42.00 & 44.15 & 13.18 & 0.67 & 100.00 \\
\hline
\end{tabular}

magmatic processes controlling, crystallization sequence and types of crystallized minerals (France, et al., 2010) [26], (Kilinc, et al., 1983) [27], (Moretti, 2005) [28], (Botcharnikov, et al., 2005) [29]. Using $\mathrm{Al}^{\mathrm{IV}}+\mathrm{Na}^{\mathrm{Vs} .} \mathrm{Al}^{\mathrm{IV}}$ $+2 \mathrm{Ti}+\mathrm{Cr}$ diagram which depend on the amount of 3 -valent iron in pyroxenes, we can get oxygen fugacity. The diagram is set based on the aluminum balance in the tetrahedral position with and $\mathrm{Cr}^{3+}$ in the octahedral position. The $\mathrm{Fe}^{3+}$ in pyroxenes can be displaced 3-valence elements such as $\mathrm{Al}{ }^{\mathrm{VI}}$, $\mathrm{Ti}$ and $\mathrm{Cr}$ in the octahedral position. In the other hand, $\mathrm{Fe}^{3+}$ in pyroxenes depends on the amount of $\mathrm{Al}^{\mathrm{VI}}$ which means it depends on the aluminum balance in tetrahedral and octahedral position. Figure 5 shows that the pyroxenes which crystallized at high oxygen fugacity, has been situated above the line of $\mathrm{Fe}^{3+}$. Furthermore, (Papike and Cameron, 1976) [30] have mentioned the distances of the samples from the $\mathrm{Fe}^{3+}$ line and noted that further distances of the samples from this line were indicating more oxygen frugalities in their geological setting. In this diagram some samples are located above the line of $\mathrm{Fe}^{3+}$ line and some are below that (Figure 5).

\section{Tectonic Setting}

Pyroxene composition depends on the chemical composition and tectonic setting of the host lava which can be used widely to determine geological setting of the rocks (Schweitzer, et al., 1979) [32], (Kushiro, 1960) [33] (Hout, et al., 2002) [34] (Figure 6). $\mathrm{Ti}+\mathrm{Cr}$ vs. $\mathrm{Ca}$ and $\mathrm{TiO}_{2}$ vs. $\mathrm{Na}_{2} \mathrm{O}+\mathrm{CaO}$ diagrams define the pyroxenes which generated by tholeiitic and calc-alkaline magmas from those of alkaline. Plotting data on $\mathrm{Ti}+\mathrm{Cr}$ vs. $\mathrm{Ca}$ and $\mathrm{TiO}_{2}$ vs. $\mathrm{Na}_{2} \mathrm{O}+\mathrm{CaO}$ diagrams show that the samples are subalkaline to alkaline tendency (Leterrier, et al., 1982) [35]. Diagrams (Figure 6) indicate the extensional setting of the area when the rocks are formed.

\section{Barometers}

The ratios $\mathrm{Al}^{\mathrm{VI}} / \mathrm{Al}^{\mathrm{IV}}, \mathrm{Ti}+\mathrm{Al}^{\mathrm{IV}} / \mathrm{Si}$ and $\mathrm{TiO}_{2} /(\mathrm{Mg}+\mathrm{Mg}+\mathrm{Fe})$ in pyroxene could be used as a pressure gauge. The diagram $\mathrm{Al}^{\mathrm{VI}} / \mathrm{Al}^{\mathrm{IV}}$ samples are in the range of moderate pressures (Figure 7(a)). Also, the structure of clinopyroxene, chrome is in equilibrium with $\mathrm{AlVi}$, The ratio of $\mathrm{Cr}^{*} 100 / \mathrm{Cr}+\mathrm{Al}^{\mathrm{VI}}$ pressure is directly related to the pyroxene (Nimis and Taylor, 2000) [36]. The aluminum content in clinopyroxene at high pressure to the Reaction $\mathrm{NaAlSi}_{3} \mathrm{O}_{8}=\mathrm{NaAlSi}_{2} \mathrm{O}_{6}+\mathrm{SiO}_{2}$ and low-pressure reaction is controlled $\mathrm{CaAl}_{2} \mathrm{Si}_{2} \mathrm{O}_{6}=\mathrm{CaAl}_{2} \mathrm{SiO}_{6}+\mathrm{SiO}_{2}(\mathrm{Green}$ and Ringwood, 1967) [37]. The first reaction in the depth of about $120 \mathrm{~km}$ (containing garnet peridotite), and the second reaction occurs at depths less than $40 \mathrm{~km}$. To determine the depth of the magma reservoir of aluminum in the pyroxene structure is used. Researchers, including (Helz, 1983) [38] have emphasized that the distribution of aluminum in the octahedral positions of tetragonal and clinopyroxene suitable criteria for estimating the water content of the magma and the pressure of the environment is the formation of igneous rocks. With this model, the pyroxene crystallized at a pressure of $5 \mathrm{kbar}$ and water content of the magma is less than 10\% (Figure 7(b)).

\section{Conclusions}

- The composition of feldspars and clinopyroxenes determined by XPMA in Torud intrusive bodies is consistent with the results obtained from determination of extinction angles in microscopic thin-sections. 


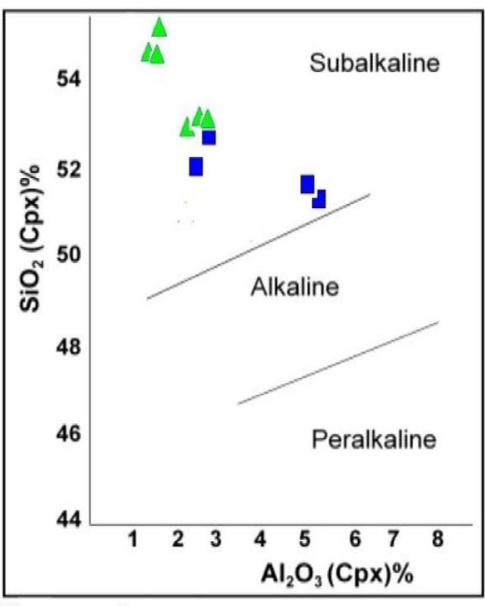

(Le Bas, 1962)

(a)

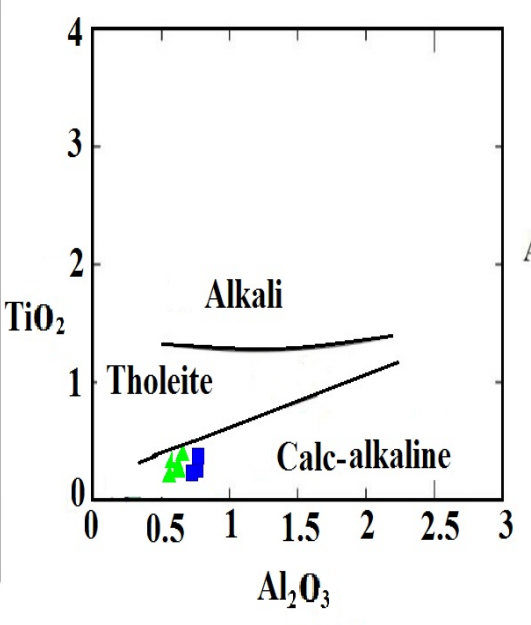

(b)

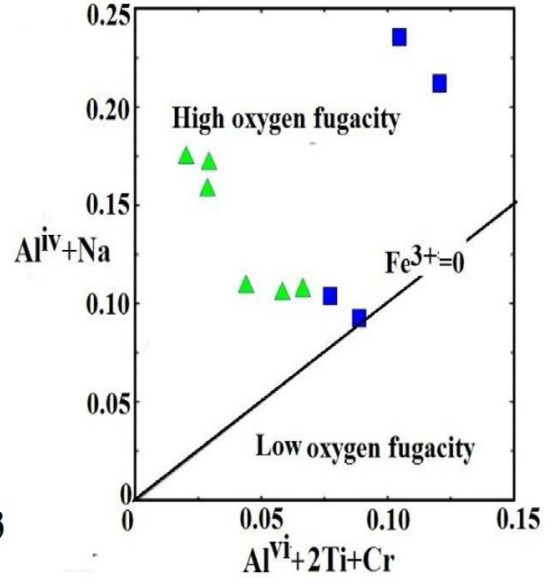

(Bence et al., 1975)

(c)

Figure 5. (a) $\mathrm{TiO}_{2}$ vs. $\mathrm{Al}_{2} \mathrm{O}_{3}$ binary diagram after (Le Bas, 1962) [31], for pyroxene; (b) $\mathrm{SiO}_{2}$ vs. $\mathrm{Al}_{2} \mathrm{O}_{3}$ binary diagram after (Le Bas, 1962) for pyroxene; (c) $\mathrm{Al}^{\mathrm{VI}}+\mathrm{Na}$ vs. $\mathrm{Al}^{\mathrm{IV}}+2 \mathrm{Ti}+\mathrm{Cr}$ diagram for Oxygen fugacity estimation of the clinopyroxenes of in volcanic rocks (Schweitzer, et al., 1979) [32].
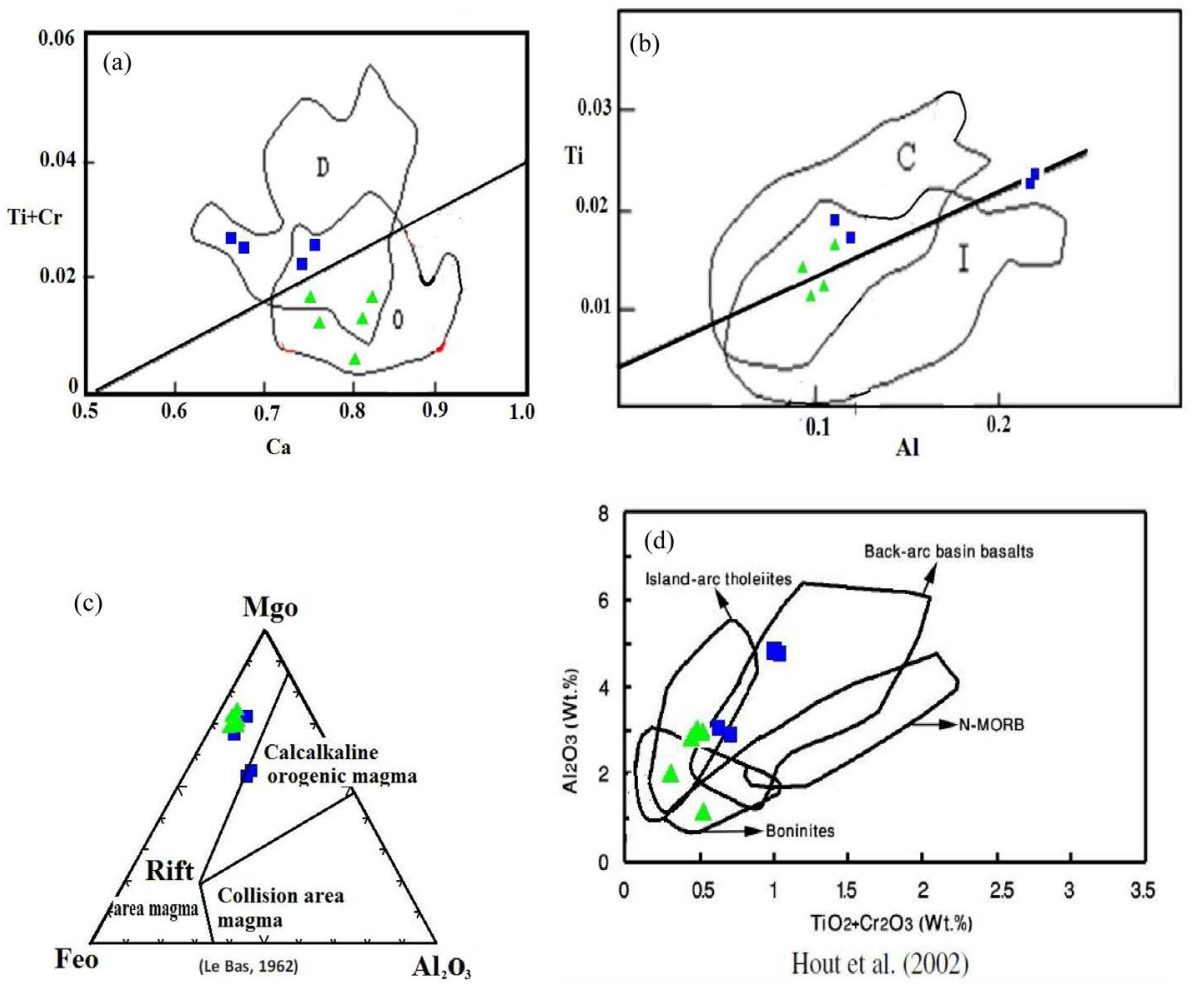

Figure 6. (a) $\mathrm{TiO}_{2}-\mathrm{Na}_{2} \mathrm{O}+\mathrm{CaO}$ diagram; (b) $\mathrm{Ti}+\mathrm{Cr}-\mathrm{Ca}$ diagram (Leterrier, et al., 1982) [35]; (c) diagram Tectonic setting (Hout, et al., 2002) [34]; (d) diagram Tectonic setting (Lebas, 1962) [31]. Abbrivation: O-Volcanic arc Basalt; D-MORB and other tholeiites of extentional setting; I-Island arc tholeiitic; C-Calc-alkaline basalt..

- Mineral types and P-T conditions of magma during crystallization can be calculated using Excel spreadsheet programs.

- The composition of clinopyroxenes, magmatic series and tectonic environments can be determined using XPMA data. 


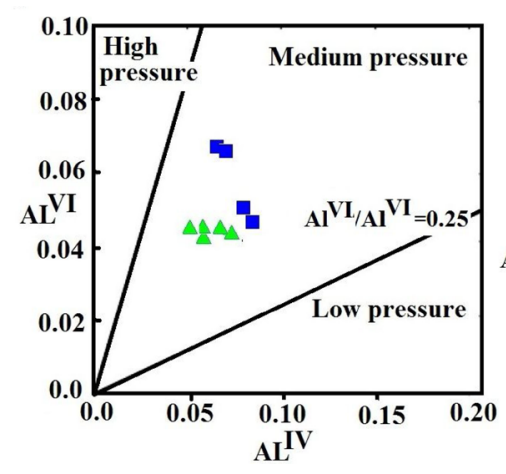

(a)

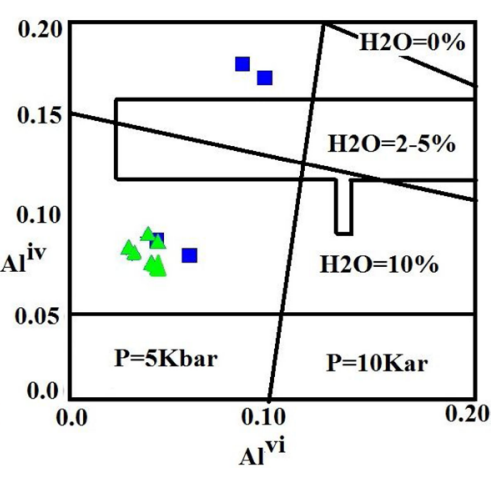

(b)

Figure 7. (a) $\mathrm{Al}^{\mathrm{VI}}$ vs. $\mathrm{Al}^{\mathrm{IV}}$ diagram (Aoki and Shiba, 1973) [39], for pressure estimation of the clinopyroxenes of in volcanic rocks. HP = High-pressure field, MP $=$ Medium-pressure field, LP = Low-pressure field. (b) diagram (Helz, 1973) [38], for pressure estimation of the clinopyroxenes of in volcanic rocks.

- The compositions of clinopyroxenes are predominantly augite and diopside according to the classification of Morimoto in 1989.

- According to the distribution of aluminum in clinopyroxenes, these minerals have been formed at $<5 \mathrm{~Kb}$ pressure and water content between 5 to 10 percent.

- The mineral compositions of the rocks display an alkaline nature which indicates a tensional setting.

\section{References}

[1] Soffel, H. and Forster, H.G. (1984) Polar Wander Depth of the Central East Iran Microplate Including New Results. Neues Jahrbuch für Geologie und Paläontologie, 198, 165-172.

[2] Alavi, M. (2004) Structures of the Zagros Fold-Thrust Belt in Iran. American Journal of Science, 307, 1064-1095.

[3] Nadimi, A. (2007) Evolution of the Central Iranian Basement. Gondwana Research, 12, 324-333.

[4] Celâl ^s:Sengör, A.M. and Yilmaz, Y. (1981) Tethyan Evolution of Turkey: A Plat Tectonic Approach. Tectonophysics, 75, 181-241. http://dx.doi.org/10.1016/0040-1951(81)90275-4

[5] Ahmadzadeh, G., Jahangiri, A., Lentz, D. and Mojtahedi, M. (2010) Petrogenesis of Plio-Quaternary Post-Collisional Ultrapotassic Volcanism in NW of Marand, NW Iran. Journal of Asian Earth Sciences, 39, 37-50. http://dx.doi.org/10.1016/j.jseaes.2010.02.008

[6] Stocklin, Y. (1973) Basic Geological Study of Central Lut, East of Iran. Report 22-F, Institute of Geology and Mining Publications, Tehran, 56.

[7] Farhoudi, G. (1978) A Comparison of Zagros Geology to Island Arcs. Journal of Geology, 86, 325-334. http://dx.doi.org/10.1086/649694

[8] Emami, M.H. (1981) Geologie de la Region de Qom. Aran (Iran) Contribution an I'etude Dynamique Etgeochemique $\mathrm{du}$ Volcanisme Tertiaire I'Iran Central. These doctoratw Earth Grenoble, Vol. 21, 489 p.

[9] Jahangiri, A. (2007) Post-Collisional Miocene Adakitic Volcanism in NW Iran: Geochemical and Geodynamic Implications. Journal of Asian Earth Sciences, 30, 433-447. http://dx.doi.org/10.1016/j.jseaes.2006.11.008

[10] Berberian, M. and King, G.C.P. (1981) Towards a Paleogeography and Tectonic Evolution of Iran. Canadian Journal of Earth Sciences, 18, 210-256. http://dx.doi.org/10.1139/e81-019

[11] Dupuy, C. and Dostal, J. (1984) Trace Element Geochemistry of Some Continental Tholeiites. Earth and Planetary Science Letters, 67, 61-69. http://dx.doi.org/10.1016/0012-821X(84)90038-4

[12] Azizi, H. and Jahangiri, A. (2008) Cretaceous Subduction-Related Volcanism in the Northern Sanandaj-Sirjan Zone, Iran. Journal of Geodynamics, 45, 178-190.

[13] Jung, D., Küsten, M. and Tarkian, M. (1976) Post-Mesozoic Volcanism in Iran and Its Relation to the Subduction of the Afro-Arabian under the Eurasian Plate. In: Pilger, A. and Rosler, A., Eds., Afar between Continental and Oceanic Rifting, E. Schweizerbart'sche Verlagsbuchhandlung, Stuttgart, 175-181.

[14] Houshmandzadeh, A.S., Alavi, M. and Pvr, R. (1357) Geological Evolution of the Phenomenon TORUD (from the 
Precambrian to the Present Covenant). Geological Survey, 138 p.

[15] Feeley, T.C. and Dungan, M.A. (1996) Compositional and Dynamic Controls on Mafic-Silicic Magma Interactions at Continental Arc Volcanoes; Evidence from Cordon El Guadal, Tatara-San Pedro Complex, Chile. Journal of petrology, 37, 1547-1577. http://dx.doi.org/10.1093/petrology/37.6.1547

[16] Nelson, S.T. and Montana, A. (1992) Sieved Textured Plagioclase in Volcanic Rocks Produced by Rapid Decompression. American Mineralogist, 77, 1242-1249.

[17] Morimoto, N. (1988) The Nomenclature of Pyroxenes. Mineralogical Magazine, 52, 425-433.

[18] Kontak, D.J., Clarck, A.H. and Pearce, T.H. (1984) Recognition of Simple and Complex Zoning in Olivine and Orthopyroxene Phenocrysts Using Laser Interference Microscopy. Mineralogical Magazine, 48, 547-550. http://dx.doi.org/10.1180/minmag.1984.048.349.11

[19] Luhr, J.F. and Carmichael, I.S.E. (1980) The Colima Volcanic Complex, Mexico. I. Post-Caldera and Esites from Volcan Colima. Contributions to Mineralogy Petrology, 71, 343-372. http://dx.doi.org/10.1007/BF00374707

[20] Grunder, A.L. and Mahood, G.A. (1988) Physical and Chemical Models of Zoned Silicic Magmas: The Loma Seca Tuff and Calabozos Caldera, Southern Andes. Journal of Petrology, 29, 831-867. http://dx.doi.org/10.1093/petrology/29.4.831

[21] Nixon, G.T. and Pearce, T.H. (1987) Laser-Interferometry of Oscillatory Zoning in Plagioclase: The Record of Magma Mixing and Phenocryst Recycling in Calc-Alkaline Magma Chambers, Iztaccihuat Volcano, Mexico. American Mineralogist, 72, 1144-1162.

[22] Morrice, M.G. and Gill, J.B. (1986) Spatial Patterns in the Mineralogy of Island Arc Magma Series: Sangihe Arc. Indonesia. Journal of Volcanology and Geothermal Research, 29, 311-353. http://dx.doi.org/10.1016/0377-0273(86)90050-8

[23] Gamble, R.P. and Taylor, L.A. (1980) Crystal/Liquid Partitioning Augite: Effects of Cooling Rate. Earth and Planetary Science Letters, 47, 21-33. http://dx.doi.org/10.1016/0012-821X(80)90100-4

[24] Ewart, A. (1979) A Review of the Mineralogy and Chemistry of Tertiary-Recent Dacitic, Latitic, Rhyolitic, and Related Salic Volcanic Rocks. In: Barker, F., Ed., Trondhjemites, Dacites and Related Rocks, Elsevier, Amsterdam, 13111.

[25] Deer, W.A., Howie, R.A. and Zussman, J. (1997) Single-Chain Silicates. Geological Society of London, London.

[26] France, L., Koepke, J., Ildefonse, B., Cichy, S.B. and Deschamps, F. (2010) Hydrous Partial Melting in the Sheeted Dike Complex at Fast Spreading Ridges: Experimental and Natural Observations. Contributions to Mineralogy and Petrology, 160, 683-704. http://dx.doi.org/10.1007/s00410-010-0502-6

[27] Kilinc, A., Carmichael, I., Rivers, M. and Sack, R. (1983) The Ferric-Ferrous Ratio of Natural Silicate Liquids Equilibrated in Air. Contributions to Mineralogy and Petrology, 83, 136-140. http://dx.doi.org/10.1007/BF00373086

[28] Moretti, R. (2005) Polymerisation, Basicity, Oxidation State and Their Role in Ionic Modelling of Silicate Melts. Annals of Geophysics, 56, 340-368.

[29] Botcharnikov, R., Koepke, J., Holtz, F., McCammon, C. and Wilke, M. (2005) The Effect of Water Activity on the Oxidation and Structural State of Fe in a Ferro-Basaltic Melt. Geochimica et Cosmochimica Acta, 69, 5071-5085.

[30] Papike, J.J. and Cameron, M. (1976) Crystal Chemistry of Silicate Minerals of Geophysical Interest. Reviews of Geophysics, 14, 37-80. http://dx.doi.org/10.1029/RG014i001p00037

[31] Le Bas, M.J., Le Maitre, R.W., Streckeisen, A. and Zanettin, B. (1986) A Chemical Classification of Volcanic Rocks Based on the Total Alkali-Silica Diagram. Journal of Petrology, 27, 745-750.

[32] Schweitzer, E.L., Papike, J.J. and Bence, A.E. (1979) Statistical Analysis of Clinopyroxenes from Deepsea Basalts. American Mineralogist, 64, 502-513.

[33] Kushiro, I. (1960) Si-Al Relation in Clinopyroxenes from Igneous Rocks. American Journal of Science, 258, 548-554. http://dx.doi.org/10.2475/ajs.258.8.548

[34] Hout, F., Hébert, R., Varfalvy, V., Beaudoin, G., Wang, C.S., Liu, Z.F., Cotten, J. and Dostal, J. (2002) The Beimarang Melange (Southern Tibet) brings Additional Constraints in Assessing the Origin, Metamorphic Evolution and Obduction Processes of the Yarlung Zangbo Ophiolite. Journal of Asian Earth Sciences, 21, 307-322. http://dx.doi.org/10.1016/S1367-9120(02)00053-6

[35] Leterrier, J., Maury, R.C., Thonon, P., Girard, D. and Marchal, M. (1982) Clinopyroxene Composition as a Method of Identification of the Magmatic Affinities of Paleo-Volcanic Series. Earth and Planetary Science Letters, 59, 139-154. http://dx.doi.org/10.1016/0012-821X(82)90122-4

[36] Nimis, P. and Taylor, W.R. (2000) Single Clinopyroxene Thermobarometery for Garnet Peridotites. Part I. Calibration and Testing of the Cr-in-Cpx Barometer and an Enstitite-in-Cpx Thermometer. Contributions to Mineralogy and Petrology, 139, 541-554. http://dx.doi.org/10.1007/s004100000156 
[37] Green, D.H. and Ringwood, A.E. (1967) An Experimental Investigation of the Gabbro to Eclogite Transformation and Its Petrological Applications. Geochimica et Cosmochimica Acta, 31, 767-833.

http://dx.doi.org/10.1016/S0016-7037(67)80031-0

[38] Helz, R.T. (1973) Phase Relations of Basalts in Their Melting Ranges at $\mathrm{P}_{\mathrm{H}_{2} \mathrm{O}}=5 \mathrm{~kb}$ as a Function of Oxygen Fugacity, Part I. Mafic Phases. Journal of Petrology, 14, 249-302. http://dx.doi.org/10.1093/petrology/14.2.249

[39] Aoki, K.I. and Shiba, I. (1973) Pyroxenes from Lherzolite Inclusions of Itinome-Gata, Japan. Lithos, 6, 41-51. http://dx.doi.org/10.1016/0024-4937(73)90078-9 
Scientific Research Publishing (SCIRP) is one of the largest Open Access journal publishers. It is currently publishing more than 200 open access, online, peer-reviewed journals covering a wide range of academic disciplines. SCIRP serves the worldwide academic communities and contributes to the progress and application of science with its publication.

Other selected journals from SCIRP are listed as below. Submit your manuscript to us via either submit@scirp.org or Online Submission Portal.
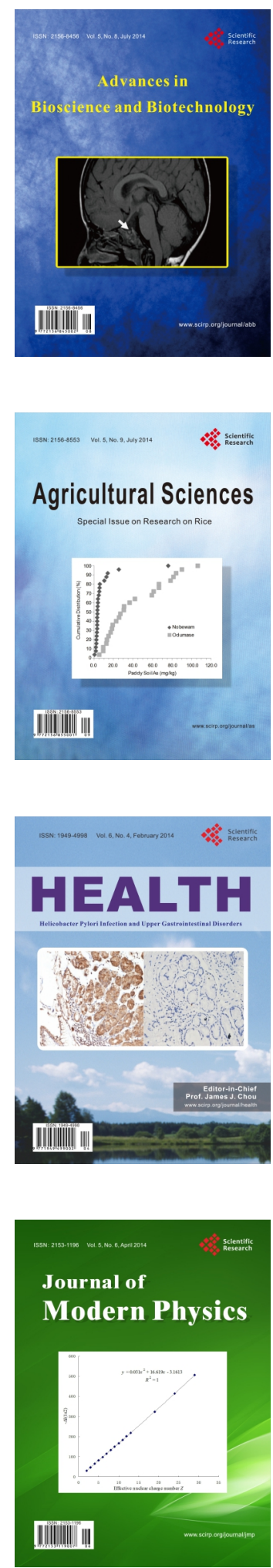
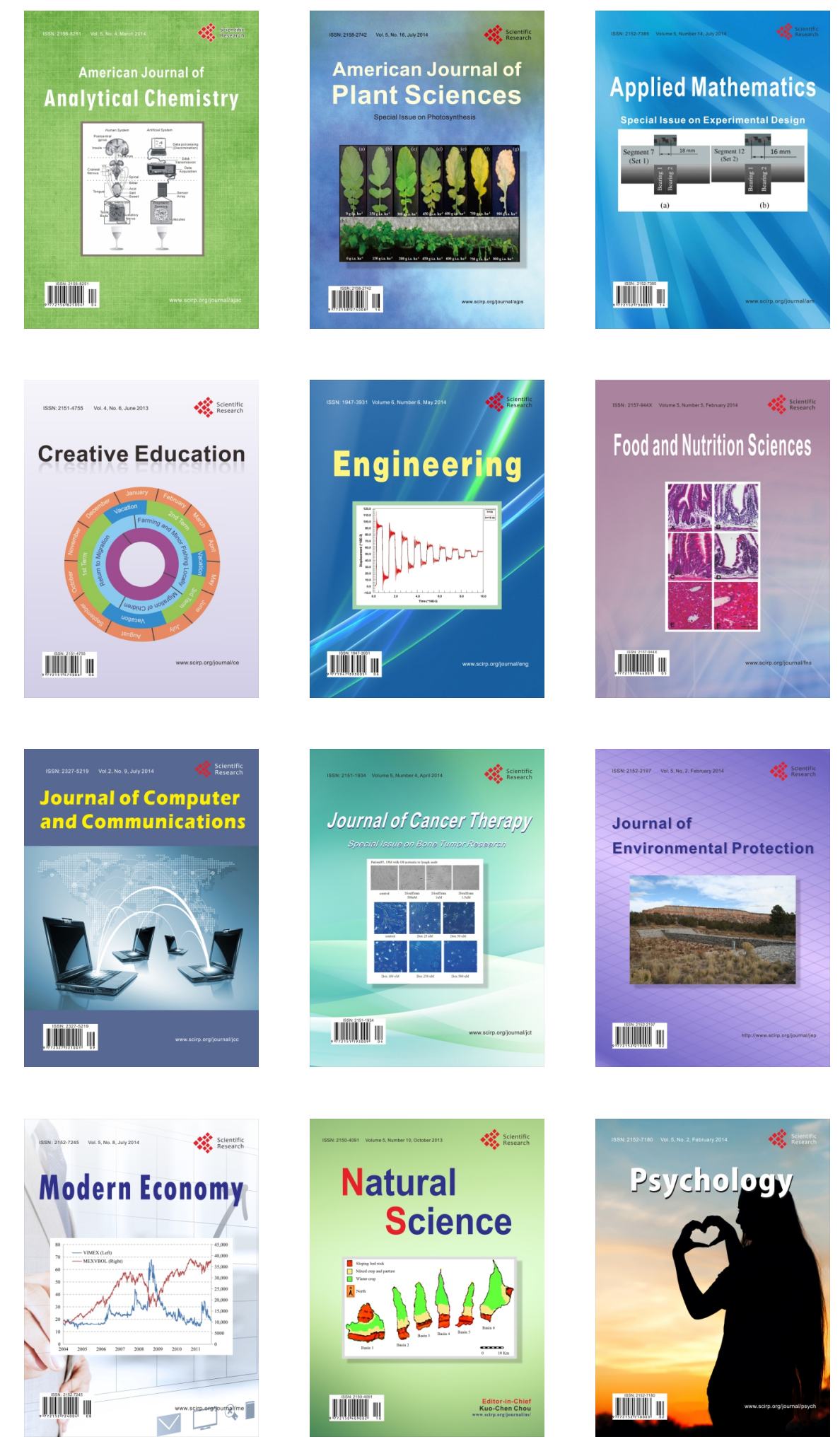